\title{
Not Lost to Follow-Up
}

National Cancer Institute

\section{Source}

National Cancer Institute. Not Lost to Follow-Up. NCI Thesaurus. Code C159823.

The individual was not lost to follow-up. 